\title{
TENT4B wt Allele
}

National Cancer Institute

\section{Source}

National Cancer Institute. TENT4B wt Allele. NCI Thesaurus. Code C118344.

Human TENT 4B wild-type allele is located in the vicinity of $16 q 12.1$ and is approximately $82 \mathrm{~kb}$ in length. This allele, which encodes non-canonical poly(A) RNA polymerase PAPD5 protein, plays a role in mRNA modification and stability. 